\title{
Stump Appendicitis: Does it Occur More Frequently after Laparoscopic or Conventional Appendectomy? - Report of a Case
}

\author{
Gina von Einem ${ }^{1, \dagger}$, Timm Denecke ${ }^{2, \dagger}$, Christian Grieser $^{2}$, Matthias Glanemann ${ }^{*}, 1$ and \\ Andreas Andreou ${ }^{1}$ \\ ${ }^{I}$ Department of General, Visceral and Transplantation Surgery, Charité - University Medicine Berlin, Campus Virchow- \\ Klinikum, Germany \\ ${ }^{2}$ Department of Radiology, Charité - University Medicine Berlin, Campus Virchow-Klinikum, Germany
}

\begin{abstract}
We here present a case of stump appendicitis as a late complication after laparoscopic appendectomy. The literature showed that the occurrence of stump appendicitis correlated with the length of the remaining appendix stump. To prevent stump appendicitis it is important to correctly identify the caecum base and to ensure the complete removal of the appendix in both surgical techniques. Should this not be possible with the laparoscopic technique, then an open resection should be considered.
\end{abstract}

Keywords: Appendicitis, surgery, appendectomy, stump appendicitis.

\section{INTRODUCTION}

Acute appendicitis is one of the most common surgical emergencies worldwide [1]. The obstruction of the appendix lumen via an appendicolith, a lymphoide hyperplasia or a neoplasia is the most common cause of inflammation of the appendix [2]. The luminal distension, which can develop due to this, constricts the perfusion of the appendix wall and leads to ischemia, which in turn can lead to a bacterial invasion with subsequent infection. A delayed surgical intervention of this condition can result in perforation of the appendix, proportionally increasing the risk between the time of diagnosis and the beginning of actual treatment. An appendectomy is usually the preferred therapy [3].

Postoperative complications are usually wound infections, postoperative hemorrhages, intra-abdominal abscess formations, adhesions, and very seldom stump appendicitis [4]. Since stump appendicitis is very uncommon, it is very often not immediately correctly diagnosed with right-sided lower abdominal pain after appendectomy, even though the clinical characteristics are similar to that of appendicitis. Indication of stump appendicitis is an infection of the remaining tissue of the supposedly completely removed appendix. This rare late complication after an appendectomy was already described the first time in 1945 by T.F. Rose [5]. Stump appendicitis can occur up to 50 years after the initial appendectomy [6], which most certainly complicates an accurate diagnosis.

Appendectomies are usually performed with open or minimal-invasive laparoscopic technique. Both techniques

\footnotetext{
*Address correspondence to this author at the Department of General, Visceral and Transplantation Surgery, Charité-University Medicine Berlin, Campus Virchow Klinikum, Augustenburger Platz 1, D-13353 Berlin, Germany; Tel: +49-30-450 552001; Fax: +49-30-450 552900; E-mail: matthias.glanemann@charite.de

${ }^{\dagger}$ Equal contribution.
}

are established procedures, which are applied in case of acute appendicitis. The first laparoscopic appendectomy was performed on September $13^{\text {th }}, 1983$, by the German Gynecologist K. Semm from the Universitätsfrauenklinik in Kiel, Germany [7]. Stump appendicitis was discovered due to advancements in laparoscopic appendectomy, and was associated with the length of the remaining stump [8]. Whilst Walsh et al. [9] reported on a possible increased risk of stump appendicitis after the laparoscopic technique, in which the stump is generally not lowered into the base of the caecum, its occurrence after both surgical techniques was however described similarly in the literature, so that the exact etiology has not as yet been completely explained [6, $10]$.

We herein report of a patient who had stump appendicitis eight weeks after laparoscopic appendectomy. We researched the Medline literature with regard to the occurrence of stump appendicitis after appendectomy, and compared the techniques to our technique (open $v s$. laparoscopic).

\section{CASE REPORT}

A 46 year old patient was admitted to our surgical emergency ward with severe abdominal pain, which he had for approximately the last 24 hours, as well as nausea, vomiting and subfebrile temperature. Eight weeks before the patient had a laparoscopic appendectomy due to acute appendicitis. The present symptoms were similar to those before the appendectomy. During the physical examination the patient was sensitive towards pressure in the right hypogastrium (McBurney and Lanz positive, leucocytes $16.02 / \mathrm{nl}$ ).

Abdominal X-ray was without pathological findings and sonography also showed nothing notable due to bowl obstructions in the region of the abdominal pain. A computed tomography finally revealed stump appendicitis with circular wall thickening at the coecal pole and inflammatory imbition of the surrounding tissue (Fig. 1). 

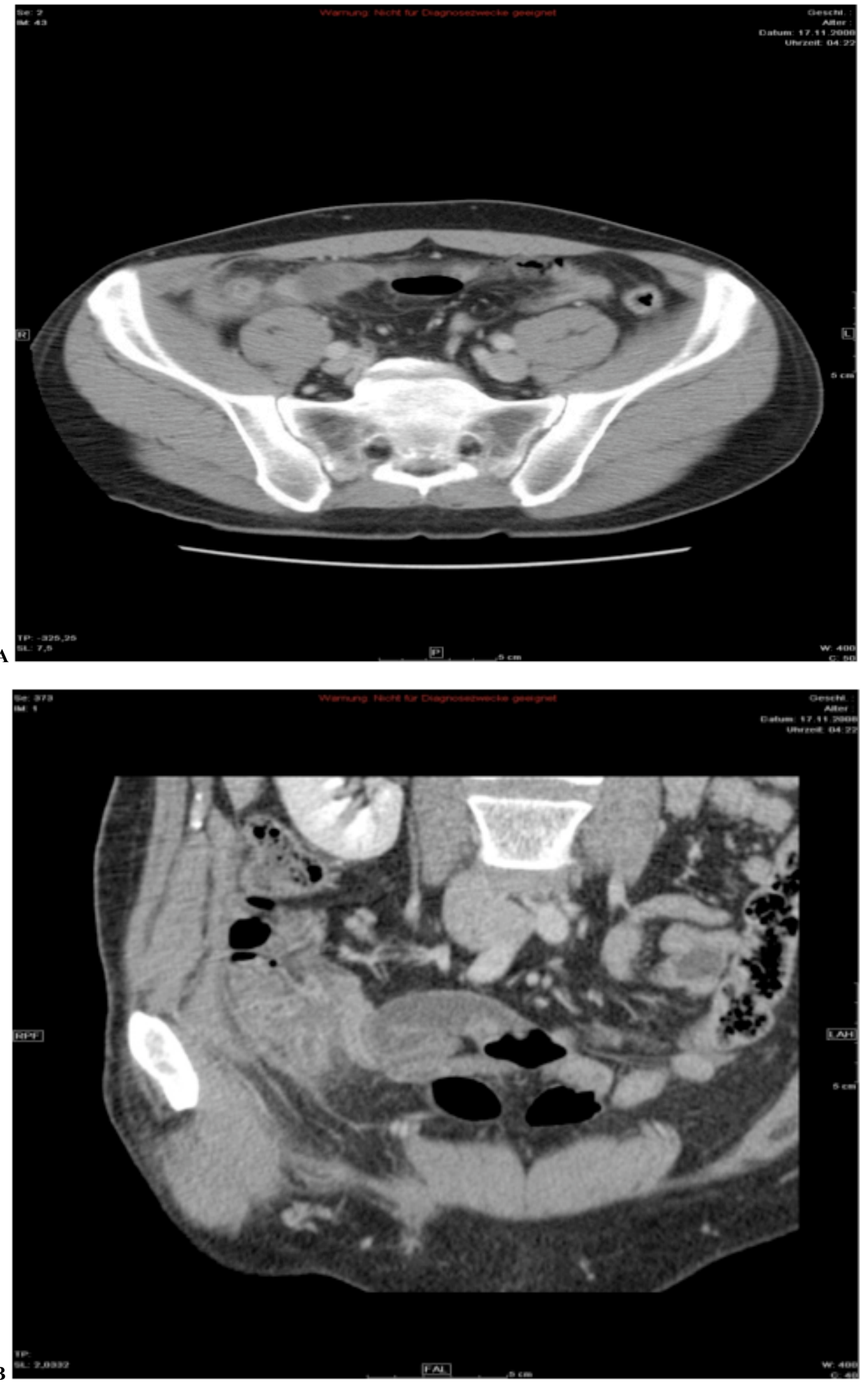

Fig. (1) A,B: CT-scan of the abdomen with inflammatory changes of the appendix stump. Circular wall thickening at the coecal pole and inflammatory imbibition of the surrounding fatty tissue correspond with the image of stump appendicitis. 
Table 1. Literature of the Stump Appendicitis Cases

\begin{tabular}{|c|c|c|c|c|c|c|c|c|c|c|c|}
\hline Author & Year & Age & & $\begin{array}{l}\text { 1st } \\
\text { op }\end{array}$ & $\begin{array}{c}\Delta t \\
\text { (months) }\end{array}$ & $\begin{array}{c}\mathrm{L} \\
(\mathrm{cm})\end{array}$ & Perforation & $\begin{array}{l}\text { Fever } \\
\left({ }^{\circ} \mathrm{C}\right)\end{array}$ & Leucocytes/nl & Diagnostic & $\begin{array}{c}\Delta t \text { post op } \\
\text { (days) }\end{array}$ \\
\hline Patel [27] & 2009 & 8 & $\mathrm{~m}$ & lap & 5 & n.a. & n.a. & n.a. & n.a. & $\mathrm{CT}+\mathrm{Km}$ & n.a. \\
\hline Mentes [28] & 2008 & 32 & $\mathrm{~m}$ & open & 144 & 1.5 & n.a. & 37.8 & 14.7 & $\mathrm{X}, \mathrm{US}$ & 4 \\
\hline Jacombs [29] & 2008 & 25 & $\mathrm{~m}$ & open & 120 & 4 & no & no & 17.2 & $\mathrm{CT}$ & 2 \\
\hline Al-Dabbagh [30] & 2008 & 41 & $\mathrm{~m}$ & n.a. & 14 & 4.5 & n.a. & n.a. & 10.4 & US & 10 \\
\hline Truty [2] & 2008 & 32 & $\mathrm{~m}$ & open & 12 & 3.5 & n.a. & yes & n.a. & $\mathrm{CT}$ & 2 \\
\hline Waseem [31] & 2007 & 15 & $\mathrm{~m}$ & lap & 24 & $0 . .6$ & n.a. & 37.5 & 10.0 & $\mathrm{CT}+\mathrm{Km}$ & 3 \\
\hline Yigit [32] & 2007 & 32 & $\mathrm{w}$ & n.a. & 144 & 1 & n.a. & n.a. & 14.7 & US & 4 \\
\hline Uludag [33] & 2006 & 47 & $\mathrm{~m}$ & open & 240 & 1 & yes & 8.4 & 11.7 & US, CT & 3 \\
\hline Liang [16] & 2006 & 32 & $\mathrm{w}$ & lap & 5 & 4 & n.a. & 37.8 & 9.3 & $\mathrm{CT}$ & 2 \\
\hline Burt [34] & 2005 & 27 & $\mathrm{~m}$ & open & 240 & n.a. & n.a. & n.a. & 20 & $\mathrm{CT}$ & n.a. \\
\hline Roche-Nagle [35] & 2005 & 35 & $\mathrm{~m}$ & n.a. & 168 & 3.5 & yes & 38.3 & 17.3 & $\mathrm{CT}$ & 8 \\
\hline Shin [18] & 2005 & 41 & $\mathrm{~m}$ & lap & 2 & 6.5 & n.a. & n.a. & 13.4 & $\mathrm{CT}+\mathrm{Km}$ & 8 \\
\hline Aschkenasy [8] & 2005 & 27 & $\mathrm{~m}$ & open & 249 & 2.2 & n.a, & 36.1 & 20.1 & $\mathrm{CT}$ & 1 \\
\hline De [36] & 2004 & 26 & $\mathrm{w}$ & open & 12 & 2.5 & n.a. & n.a. & 13.3 & $\mathrm{X}+\mathrm{Km}$ & 10 \\
\hline Watkins [10] & 2004 & 62 & $\mathrm{w}$ & lap & 9 & 5.5 & yes & 37 & 12.4 & $\mathrm{CT}$ & 5 \\
\hline Levine [37] & 2004 & 31 & $\mathrm{~m}$ & lap & n.a. & n.a. & n.a. & n.a. & n.a. & $\mathrm{CT}$ & n.a. \\
\hline Durgun [38] & 2003 & 68 & $\mathrm{w}$ & open & 8 & 3 & yes & 38.8 & 16.4 & Lap & 10 \\
\hline \multirow[t]{2}{*}{ Marcoen [39] } & 2003 & 49 & $\mathrm{~m}$ & lap & 6 & 4 & n.a. & 37.8 & 12.3 & X,CT,US & 7 \\
\hline & & 14 & $\mathrm{w}$ & lap & 12 & 5 & n.a. & 38 & n.a. & X,CT,US & n.a. \\
\hline Nahon [23] & 2002 & 33 & $\mathrm{~m}$ & open & 18 & n.a. & n.a. & 38 & 8.4 & CT,Colo & n.a. \\
\hline \multirow[t]{3}{*}{ Mangi [6] } & 2000 & 43 & $\mathrm{w}$ & open & 480 & 0.5 & yes & no & 13 & $\mathrm{CT}$ & n.a. \\
\hline & & 64 & $\mathrm{~m}$ & open & n.a. & 0.6 & yes & no & n.a. & Lap & n.a. \\
\hline & & 63 & $\mathrm{w}$ & open & 600 & n.a. & yes & n.a. & 18.8 & Lap & n.a. \\
\hline Baldisserotto [40] & 2000 & 13 & w & open & 2 & n.a. & yes & 39 & 14 & US & n.a. \\
\hline Gupta [22] & 2000 & 11 & $\mathrm{~m}$ & lap & 12 & 4.5 & yes & yes & 20.3 & $\mathrm{CT}$ & 16 \\
\hline Rao [19] & 1998 & 39 & $\mathrm{w}$ & open. & 408 & 1.6 & yes & 38 & 19.4 & US,CT & 6 \\
\hline Erzurum [20] & 1997 & 11 & $\mathrm{w}$ & open & 8 & 3.5 & yes & 39.2 & 19 & $\mathrm{CT}$ & 5 \\
\hline Walsh [9] & 1997 & 72 & $\mathrm{w}$ & lap & 5 & 2.5 & n.a. & yes & n.a. & $\mathrm{X}$ & 10 \\
\hline Demartines [41] & 1996 & 32 & $\mathrm{w}$ & open & 120 & n.a. & n.a. & n.a. & n.a. & Lap & n.a. \\
\hline Milne [42] & 1996 & 25 & $\mathrm{~m}$ & lap & 18 & 3 & yes & 37.8 & 18 & $\mathrm{X}$ & 11 \\
\hline $\begin{array}{l}\text { Filippi de la Palavesa } \\
{[43]}\end{array}$ & 1996 & 25 & $\mathrm{~m}$ & lap & 24 & n.a. & n.a. & yes & n.a. & US,CT & n.a. \\
\hline Thomas [17] & 1994 & 53 & $\mathrm{w}$ & open & 252 & n.a. & yes & 38.7 & 21 & $\mathrm{CT}$ & 8 \\
\hline Devereaux [15] & 1994 & 49 & $\mathrm{~m}$ & lap & 2 & 2 & yes & n.a. & n.a. & Lap & 14 \\
\hline Siegel [44] & 1954 & 51 & $\mathrm{w}$ & open & 168 & 1.3 & yes & 39.4 & 27 & $\mathrm{X}+\mathrm{Km}$ & 35 \\
\hline \multirow[t]{2}{*}{ Rose [5] } & 1945 & 23 & $\mathrm{~m}$ & open & 12 & 5.1 & yes & n.a. & n.a. & n.a. & n.a. \\
\hline & & 40 & $\mathrm{~m}$ & open & 24 & 5.1 & yes & n.a. & n.a. & n.a. & n.a. \\
\hline Own case & 2009 & 46 & $\mathrm{~m}$ & lap & 2 & 5 & no & yes & 16 & $\begin{array}{l}\text { US, CT+KM, } \\
\text { Lap }\end{array}$ & 4 \\
\hline
\end{tabular}

Legend: 1. Op: primary operation, $\mathrm{L}(\mathrm{cm})$ : length of the appendix stump in $\mathrm{cm}, \Delta \mathrm{t}$ : interval between the first appendicitis and the stump appendicitis, $\Delta \mathrm{t}$ post Op: postoperative hospital stay, n.a: not specified, lap: laparoscopic, X: X-rays of abdomen, Km: contrast medium, Colo: colonscopy, US: sonography of abdomen, CT: computed tomography of abdomen 
A reoperation in laparoscopic technique was performed, which showed a local fibrinogenous infection in the right abdomen. The local adhesions of the greater omentum were separated, revealing an approximately $5 \mathrm{~cm}$ long appendix stump, which was ballooned at the distal end, and which discharge a murky liquid secretion when touched with a soft pair of pliers. It was noticed that a PDS loop was used to remove the appendix. The appendix stump was normal in the region of the caecum. By carefully dissecting and detaching the adherent fatty tissue, it was possible to mobilize the appendix stump. Thereafter the appendix stump was removed from the base of the caecum with an Endo-GIA (Fa. Ethicon, Norderstedt, Germany). The histological examination of the resected specimen revealed a mucous membrane of the colon with a chronic granulated and fibrinous purulent serositis reaching well into the submucosa, however without any signs of a dysplasia or malignancy. On the 4th postoperative day the patient was dismissed without any surgical complications.

\section{DISCUSSION}

Currently surgical resection is the standard treatment option for acute appendicitis. Since laparoscopic appendectomy was first described in 1983 [7], this technique is, apart from the open appendectomy, used more often nowadays. The main concern during the development of these two techniques was the management of the appendix stump after resection. Some studies have shown that with a simple ligature the development of intramural abscesses, invaginations and adhesions can be prevented [11, 12], whereas some say that lowering the stump would minimize the contamination of the abdomen, the development of adhesions and the risk of secondary hemorrhage [13]. Open appendectomy is usually performed by lowering the appendix stump, however with the laparoscopic version the appendix is removed and the stump is not lowered or sutured.

During the last 17 years laparoscopic appendectomy has proved itself to be a very safe method compared to the open technique, reducing the time of hospitalization, the use of painkillers and the occurrence of adhesive strangulation of the intestine. It has however been reported in the literature that the occurrence of stump appendicitis is associated to the more frequently used laparoscopic technique $[9,14,15]$, although most cases of stump appendicitis are reported after open appendectomy $[10,16]$. In fact, $55 \%$ of the cases occurred after open appendectomy, as shown in our Medline literature of 35 cases (Table 1).

An important prerequisite for the prevention of stump appendicitis is the complete resection of the appendix during the primary operation. Several authors have actually associated the occurrence of stump appendicitis to the length of the remaining appendix stump [17-21]. Our literature analysis of 35 patients with stump appendicitis showed, that after laparoscopic intervention the remaining appendix stump with an average length of $3.9 \mathrm{~cm}$, was statistically significantly $(\mathrm{p}=0.48)$ longer than after open appendectomies $(2.6 \mathrm{~cm})$. This underlines that the preparation of the caecum base demands a lot of attention during an appendectomy (Table 2).
Table 2. Comparison of Characteristics of Patients with Stump Appendicitis after Open or Laparoscopic Appendectomy

\begin{tabular}{|c|c|c|c|}
\hline & Open & Lap. & p \\
\hline \hline Age (years) & $38.82 \pm 3.0$ & $34.29 \pm 5.2$ & 0.428 \\
\hline $\begin{array}{c}\text { Time between primary and } \\
\text { secondary operation (months) }\end{array}$ & $163.86 \pm 36.6$ & $9.69 \pm 2.2$ & 0.000 \\
\hline $\begin{array}{c}\text { Stump length (cm) of the } \\
\text { remaining appendix }\end{array}$ & $2.582 \pm 0.37$ & $3.873 \pm 0.52$ & 0.048 \\
\hline Leucocytes (amount/nl) & $16.6 \pm 11.0$ & $13.9 \pm 13.6$ & 0.168 \\
\hline $\begin{array}{c}\text { Duration of hospital stay after } \\
\text { reoperation (days) }\end{array}$ & $7.71 \pm 2.3$ & $8.44 \pm 1.6$ & 0.817 \\
\hline
\end{tabular}

The most common reason for an incomplete appendix removal is the not always easily indentifiable caecum base. This can be prevented if the appendicular artery is dissected and ligated, since it marks the base of the caecum [22]. A further technique identifying the correct resection margin is to follow the colic taeniae right up to the appendix [23, 24]. Laparoscopic appendectomy can due it's restricted vision, the unavailable three-dimensionality, the limited palpation possibility as well as the careful preparation of the caecum base with the diathermy instruments, possibly benefit the development of stump appendicitis $[9,25,26]$. Surgical conditions can, apart from various other reasons, become complicated due to inflammatory changes of the surrounding tissue. It should be the aim in each case to perform a complete resection of the appendix, should this however not be possible with the laparoscopic method, then it should be done with the open technique.

\section{REFERENCES}

[1] Humes DJ, Simpson J. Acute appendicitis. BMJ 2006; 333(7567): 530-4.

[2] Truty MJ, Stulak JM, Utter A, Solberg J, Degnim AC. Appendicitis after appendectomy. Arch Surg 2008; 143(4): 413-5.

[3] Bickell NA, Aufses AH Jr, Rojas M, Bodian C. How time affects the risk of rupture in appendicitis. J Am Coll Surg 2006; 202(3): 401-6.

[4] Hale DA, Molloy M, Pearl RH, Schutt DC, Jaques DP. Appendectomy: a contemporary appraisal. Ann Surg 1997; 225(3): 252-61.

[5] Rose T. Recurrent appendiceal abscess. Med J Aust 1945; 32: 65962 .

[6] Mangi AA, Berger DL. Stump appendicitis. Am Surg 2000; 66(8): 739-41.

[7] Semm K. Endoscopic appendectomy. Endoscopy 1983; 15(2): 5964.

[8] Aschkenasy MT, Rybicki FJ. Acute appendicitis of the appendiceal stump. J Emerg Med 2005; 28(1): 41-3.

[9] Walsh DC, Roediger WE. Stump appendicitis - a potential problem after laparoscopic appendicectomy. Surg Laparosc Endosc 1997; 7(4): 357-8.

[10] Watkins BP, Kothari SN, Landercasper J. Stump appendicitis: case report and review. Surg Laparosc Endosc Percutan Tech 2004; 14(3): 167-71.

[11] Stree D, Bodai BI, Owens LJ, et al. Simple ligation vs. stump inversion in appendectomy. Arch Surg 1988; 123(6): 689-90.

[12] Cleland G. Caecocolic intussusception following appendicectomy. Br J Surg 1953; 41(165): 108-9.

[13] Sinha AP. Appendicectomy: an assessment of the advisability of stump invagination. Br J Surg 1977; 64(7): 499-500. 
[14] Greenberg JJ, Esposito TJ. Appendicitis after laparoscopic appendectomy: a warning. J Laparoendosc Surg 1996; 6(3): 185-7.

[15] Devereaux DA, McDermott JP, Caushaj PF. Recurrent appendicitis following laparoscopic appendectomy. Report of a case. Dis Colon Rectum 1994; 37(7): 719-20.

[16] Liang MK, Lo HG, Marks JL. Stump appendicitis: a comprehensive review of literature. Am Surg 2006; 72(2): 162-6.

[17] Thomas SE, Denning DA, Cummings MH. Delayed pathology of the appendiceal stump: a case report of stump appendicitis and review. Am Surg 1994; 60(11): 842-4.

[18] Shin LK, Halpern D, Weston SR, Meiner EM, Katz DS. Prospective CT diagnosis of stump appendicitis. AJR Am J Roentgenol 2005; 184(3 Suppl): S62-4.

[19] Rao PM, Sagarin MJ, McCabe CJ. Stump appendicitis diagnosed preoperatively by computed tomography. Am J Emerg Med 1998; 16(3): 309-11.

[20] Erzurum VZ, Kasirajan K, Hashmi M. Stump appendicitis: a case report. J Laparoendosc Adv Surg Tech A 1997; 7(6): 389-91.

[21] Feigin E, Carmon M, Szold A, Seror D. Acute stump appendicitis. Lancet 1993; 341(8847): 757.

[22] Gupta R, Gernshiemer J, Golden J, Narra N, Haydock T. Abdominal pain secondary to stump appendicitis in a child. $\mathrm{J}$ Emerg Med 2000; 18(4): 431-3.

[23] Nahon P, Nahon S, Hoang JM, Traissac L, Delas N. Stump appendicitis diagnosed by colonoscopy. Am J Gastroenterol 2002; 97(6): 1564-5.

[24] Scott-Conner CE, Hall TJ, Anglin BL, Muakkassa FF. Laparoscopic appendectomy. Initial experience in a teaching program. Ann Surg 1992; 215(6): 660-7.

[25] Greene JM, Peckler D, Schumer W, Greene EI. Incomplete surgical removal of the appendix; its complications. J Int Coll Surg 1958; 29(2, Part 1): 141-6.

[26] Wright TE, Diaco JF. Recurrent appendicitis after laparoscopic appendectomy. Int Surg 1994; 79(3): 251-2.

[27] Patel RP, Kan J. Stump appendicitis. Pediatr Radiol 2009; 39(3): 306.

[28] Mentes O, Zeybek N, Oysul A, Önder SC, Tufan T. Stump appendicitis, rare complication after appendectomy: report of a case. Ulus Travma Acil Cerrahi Derg 2008; 14(4): 330-2.
[29] Jacombs A, Webb G, Leibman S. Right iliac fossa pain 10 years after appendicectomy and the diagnosis of stump appendicitis. ANZ J Surg 2008; 78(8): 711-2.

[30] Al-Dabbagh AK, Thomas NB, Haboubi N. Stump appendicitis. A diagnostic dilemma. Tech Coloproctol 2009; 13(1): 73-4.

[31] Waseem M, Devas G. A child with appendicitis after appendectomy. J Emerg Med 2008; 34(1): 59-61.

[32] Yigit T, Mentes O, Eryilmaz M, et al. Stump resections resulting from incomplete operations. Am Surg 2007; 73(1): 75-8.

[33] Uludag M, Isgor A, Basak M. Stump appendicitis is a rare delayed complication of appendectomy: A case report. World J Gastroenterol 2006; 12(33): 5401-3.

[34] Burt BM, Javid PJ, Ferzoco SJ. Stump appendicitis in a patient with prior appendectomy. Dig Dis Sci 2005; 50(11): 2163-4.

[35] Roche-Nagle G, Gallagher C, Kilgallen C, Caldwell M. Stump appendicitis: a rare but important entity. Surgeon 2005; 3(1): 53-4.

[36] De U, De Krishna K. Stump Appendicitis. J Indian Med Assoc 2004; 102(6): 329 .

[37] Levine CD, Aizenstein O, Wachsberg RH. Pitfalls in the CT diagnosis of appendicitis. Br J Radiol 2004; 77(921): 792-9.

[38] Durgun AV, Baca B, Ersoy Y, Kapan M. Stump appendicitis and generalized peritonitis due to incomplete appendectomy. Tech Coloproctol 2003; 7(2): 102-4.

[39] Marcoen S, Onghena T, Van Loon C, Vereecken L. Residual appendicitis following incomplete laparoscopic appendectomy. Acta Chir Belg 2003; 103(5): 517-8.

[40] Baldisserotto M, Cavazzola S, Cavazzola TL, Lopes MH, Mottin CC. Acute edematous stump appendicitis diagnosed preoperatively on sonography. AJR Am J Roentgenol 2000; 175(2): 503-4.

[41] Demartines N, Largiader J. 'Residual' appendicitis following incomplete laparoscopic appendectomy. Br J Surg 1996; 83(10): 1481 .

[42] Milne AA, Bradbury AW. 'Residual' appendicitis following incomplete laparoscopic appendicectomy. Br J Surg 1996; 83(2): 217.

[43] Filippi de la Palavesa MM, Vaxmann D, Campos M, et al. Appendiceal stump abscess. Abdom Imaging 1996; 21(1):65-6.

[44] Siegel SA. Appendiceal stump abscess; a report of stump abscess twenty-three years postappendectomy. Am J Surg 1954; 88(4): $630-2$. 